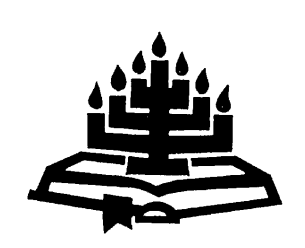

\title{
Die Nuwe Hervorming: verwagting of verydeling? ${ }^{1}$
}

\author{
J.H. van Wyk \\ Navorser: Skool vir Kerkwetenskappe \\ Potchefstroomse Universiteit vir $\mathrm{CHO}$ \\ POTCHEFSTROOM \\ E-pos: amievw@intekom.co.za
}

\begin{abstract}
The New Reformation: Expectation or frustation?

In the Reformed-Christian tradition the idea of a continuing reformation is - and should never be questioned: "ecclesia reformata semper reformanda". The relevant question should be: what kind of reformation should be expected? In this article the author critically investigates the claims of the so-called New Reformation that were widely discussed in daily newspapers during 2002. The views of the New Reformation as far as the doctrines of God, Christology, ecclesiology, eschatology and Scripture are concerned, are scrutinised and evaluated in this article. The author discovers a very close relationship - in many ways - between the views of the New Reformation and that of Rudolf Bultmann, who was strongly influenced by the Aufklärung of the eighteenth century. The author concludes that the New Reformation, although there are some aspects that should be appreciated, cannot (in totality) be typified as a "new reformation" - it is not "new" and does not represent a "reformation".

Opsomming
\end{abstract}

Die Nuwe Hervorming: verwagting of verydeling?

In die reformatoriese Christelike tradisie is - en behoort - die idee van 'n voortdurende reformasie nooit bevraagteken te word nie: "ecclesia reformata semper reformanda". Die tersaaklike vraag behoort te lui: watter soort reformasie moet verwag word? In hierdie artikel word die aansprake van die sogenaamde Nuwe Hervorming wat in 2002 wyd in dagblaaie bespreek is, deur die skrywer aan 'n

$1 \quad$ Hierdie artikel het oorspronklik gedien as voordrag tydens die Konvent van Reformatoriese Kerke in Suider-Afrika gehou in Laudium, Pretoria op 5 Maart 2003. Dit is hierna vir publikasie gereed gemaak. 
kritiese ondersoek onderwerp. Die standpunte van die Nuwe Hervorming ten opsigte van die Godsleer, Christologie, ekklesiologie, eskatologie en Skrifleer word ondersoek en geëvalueer. Die outeur ontdek - in talle opsigte - 'n noue verhouding tussen die standpunte van die Nuwe Hervorming en dié van Rudolf Bultmann, wat weer sterk deur die Aufklärung van die agtiende eeu beïnvloed is. Die skrywer konkludeer dat die Nuwe Hervorming, alhoewel daar waardering vir bepaalde aspekte daarvan kan wees, in sy geheel nie as 'n "nuwe hervorming" getipeer kan word nie - dit is nie "nuut" en ook nie 'n "hervorming" nie.

\section{Inleiding en agtergrond}

Wanneer oor die tema Die Nuwe Hervorming: verwagting of verydeling nagedink word, is dit belangrik om te weet wat met Nuwe Hervorming bedoel word. Wat ís die Nuwe Hervorming presies? Wat wíl dit? Hóé het dit begin? Wáárom het dit begin? Is daar behoefte aan 'n nuwe hervorming? Wat is núút in die Nuwe Hervorming? Wat is hervórming in die Nuwe Hervorming? Al hierdie en talle ander vrae is belangrik as ons oor die verwagting of verydeling van die Nuwe Hervorming wil handel. Uiteraard is dit nie moontlik om binne die bestek van een artikel op alle vrae asook die talle nuanses 2 binne die Nuwe Hervorming self in te gaan nie, sodat veral op enkele hoofsake gekonsentreer sal word.

Na die verskyning van die boek Die Nuwe Hervorming 3 in 2002 onder redaksie van Piet Muller, verkeer ons in die baie gunstige posisie waar dit nie meer nodig is om uit brokstukkies hier en daar, in koerante en tydskrifte 'n geheelbeeld van die Nuwe Hervorming te probeer

2 Vergelyk in hierdie verband die hoofstuk van W. Jordaan (kyk Muller, 2002:38-62). Hierdie hoofstuk verraai min direkte invloed van die Nuwe Hervorming en sou ook in 'n totaal ander konteks kon inpas. Jordaan verwys byvoorbeeld twee keer in positiewe sin na Willie Jonker (p. 45, 58), wie se teologie ver verwyderd lê van die Nuwe Hervorming, en so ook na Johan Cilliers wat skryf oor "die diepste troos van die evangelie" (p. 48). Maar ook aan die beskouings van Cilliers is die ontmitologiseringsprogram vreemd (vgl. slegs Cilliers, 2001:185-198). In 'n latere artikel in Beeld van 25 Junie 2003 problematiseer Jordaan egter die maagdelike geboorte en die liggaamlike opstanding van Jesus.

3 Die verskillende artikels van die verskillende outeurs in die boek van Muller (2002) word nie in die bronnelys afsonderlik vermeld nie; waar hulle standpunte in die artikel aangehaal word, word na "kyk Muller, 2002" verwys. Vergelyk in hierdie verband die redelik kritieklose resensies van Muller (2002) deur Barry van der Merwe in Beeld (30 Des. 2002) en deur Annelie Ferreira in Die Burger (16 Des. 2002).

[Nie alle terloopse verwysings na korrespondensie en artikels in dagblaaie is as bibliografiese inskrywings gedokumenteer nie, omdat dit die biblografie onnodig lank sou maak. Die dagblad se besonderhede word egter kortliks in die artikel self vermeld $-\mathrm{JHvW}$.] 
rekonstrueer nie. $\mathbf{4}$ Tot en met die verskyning van hierdie boek was talle standpunte van die Nuwe Hervorming vaag, onduidelik en selfs dubbelslagtig. Die boek van Muller bied egter 'n goeie beeld van hoe daar deur die Nuwe Hervormers gedink word. Wat dadelik opval as na die name van die outeurs gekyk word, is dat die teoloë onder hulle verbonde is aan teologiese fakulteite wat nie direk met predikantsopleiding verbind is nie (Unisa byvoorbeeld) en hulle ook nie aan kuratoria verantwoording verskuldig is nie. Hieruit mag natuurlik nie die konklusie getrek word dat daar nie groot simpatie van ander teoloë vir die standpunte van die Nuwe Hervorming bestaan nie, want in 'n baie groot mate hang die debat saam met die studieresultate van die Jesus-Seminaar en met die teologie van die Duitse Nuwe-Testamentikus, Rudolf Bultmann (18841976).

Piet Muller (kyk Muller, 2002:7-11) bied 'n kort oorsig van hoe die debat verloop het. Al was daar al voor die tyd kleiner skermutselings tussen teoloë5, begin die groot debat eintlik met 'n artikel van Muller in Beeld van 25 Januarie 2002, gevolg deur 'n skerp reaksie daarop deur die (haas sterwende) Murray Janson in Beeld van 13 Februarie 2002.6 Die debat word in verskeie dagblaaie voortgesit, gevolg deur 'n hele reeks verklarings en getuienisse, soos byvoorbeeld dié van die NGK teologiese professore van UP (April 2002), die NGK professore van die UV (Mei 2002)7, die teologiese professore van die GKSA (Julie 2002), die Kommissie van die Algemene Kerkvergadering van die NHKA ${ }^{8}$ (Julie

$4 \quad$ Een van die kortste en duidelikste samevattings van die Nuwe Hervorming is te vind by Wolmarans (2002d:15-18; vgl. ook sy hoofstuk in Muller, 2002:196-224).

5 Hoewel Ben du Toit (2002) se boek oor God deur sommige as die aanloop tot die Nuwe Hervorming gesien word, moet daarop gewys word dat hy aan die soendood en liggaamlike opstanding van Jesus vashou (Du Toit, 2000:150-153). Vir 'n kritiese bespreking van Du Toit se boek, vergelyk onder andere Van Wyk (2001:141-146) en Du Rand et al. (2001:10).

$6 \quad$ Vergelyk ook die boek van Janson (2001:78-112), waarin hy die Jesus-Seminaar skerp afwys.

$7 \quad$ Vir ander kritiese reaksies, vergelyk onder andere die skrywe van 'n aantal NGK leraars in Die Kerkbode van 2 Augustus 2002 (Barry et al., 2002); Stander (Die Kerkbode: 6 Sept. 2002, p. 11); Burger (Algemene Kerkbode (Aug. 2002); Van Wyk (J.H.) (Die Kerkblad: 3 Julie 2002a, p. 8-10); Van Zyl (Die Kerkbode: 1 Nov. 2002, p. 9): "Dit lyk my daar kom 'n punt waar die weë skei, waar 'n mens moet kies ...").

8 Die redakteur (D.J.C. van Wyk jnr.) van Die Hervormer skryf in die uitgawe van 15 Junie 2002, p. 2: "In 'n Bybels-reformatoriese kerk kan die weg van die Nuwe Hervorming nie gegaan word nie." In Die Hervormer van 15 Junie 2003 (p. 4) vervolg hy met: "Daar kan 'n punt kom waar akkommodering van verskillende aksente en nuanses nie meer moontlik is nie. Dit gebeur waarskynlik tans in die protes wat teen 'n vorm van vrysinnige teologie bestaan soos dit vanuit die geledere van die sogenaamde Nuwe Hervormers na vore kom." Vergelyk ook D.J.C. van Wyk (snr.) (2002:3). 
2002) (vir hierdie dokumente, vgl. die uitgawe van Woord en Daad, 380, 2002). Ook die Ring van Waterberg van die NHKA het 'n Herderlike skrywe oor die Nuwe Hervorming laat uitgaan (Die Hervormer, 1 September 2002, p. 3). In al hierdie dokumente word kritiek uitgespreek teen die beskouings van die Nuwe Hervorming asook teen die JesusSeminaar.

In 2003 het die stroom van kritiese afwysings teen die Nuwe Hervorming voortgegaan. Die ASK van die NGK het hom ook aan die begin van 2003 in 'n verklaring teen die Nuwe Hervorming uitgespreek. Ook die Hervormingsgetuienis in Die Kerkbode onder leiding van prof. Hoffie Hofmeyr en ander het 'n kritiese noot laat hoor (Kerkbode, 14 Maart, 2003 , p. 14) en so ook die Konvent van Reformatoriese Kerke in SuiderAfrika wat in Maart in Laudium, Pretoria vergader het (kyk die artikel in Die Kerkblad, Mei 2003, p. 41-42).

Tans is die debat volstoom aan die gang, ook gestimuleer deur König (2002b:285-286) se kritiek teen die Jesus-Seminaar in sy boek Ek glo die Bybel,9 hoewel H.W. van der Westhuizen reeds in 2000 van 'n nuwe ongeloof (ten opsigte van die Jesus-Seminaar) begin praat het.10 Dit is natuurlik 'n ope vraag of die standpunte van die Nuwe Hervorming identies is aan dié van die Jesus-Seminaar (Craffert, kyk Muller, 2002: 169-172 skryf byvoorbeeld krities oor die Jesus-Seminaar), hoewel daar tog duidelik aantoonbare parallelle aanwesig is en sommige Nuwe Hervormers hulle ook telkens beroep op byvoorbeeld Crossan, 'n leidende figuur in die Jesus-Seminaar (soos byvoorbeeld J. \& C. Kriel, kyk Muller, 2002:143, 148, 150).

Dit is belangrik om vanuit die staanspoor rekening te hou met die edel motiewe van die Nuwe Hervorming. "Daar is baie Christene wat graag hulle geloof in terme van die Christelike godsdiens wil uitdruk maar hulle besef hulle kan dit nie meer doen aan die hand van die tradisionele dogmas nie. 'n Nuwe hervorming is dus onafwendbaar" (Spangenberg, kyk Muller, 2002:103). Die Nuwe Hervorming "soek in die lig van die postmoderne wêreldbeeld na alternatiewe maniere om die Christelike tradisie te verwoord" (Craffert, kyk Muller, 2002:79). Die Nuwe Her-

As mense nie meer die betekenis van die kruis en opstanding van Jesus aanvaar soos ons dit in die Nuwe Testament kry nie, het hulle nie meer dieselfde geloof nie" (König, 2002b:288).

10 Dat daar al wel harde woorde in die debat geval het, kan nie ontken word nie. Vergelyk in dié verband Craffert se opmerking oor Janson, König en Durand as "struikrowers"; "meer as die helfte van wat in die Nuwe-Testamentiese akademiese wêreld gebeur, is nooit aan König vertel nie" (Craffert, soos gerapporteer deur Neels Jackson in Beeld, 11 April 2002, p. 3). Vergelyk hier die opmerking van König (2002b:286). 
vorming wil nie noodwendig die sentrale elemente van die Christelike tradisie verwerp nie, maar wil dit "wel anders verwoord" (Craffert, kyk Muller, 2002:81). Die Nuwe Hervorming "verwoord talle leerstellings anders, verwerp 'n letterlike lees van tekste buite konteks en verkondig inderdaad ' $n$ ander weergawe van die Christelike geloof' (Craffert, Beeld, 18 Sept. 2002, p. 13) (kursivering - JHvW.) So wil die Nuwe Hervorming nuwe inhoud aan ou Bybelse begrippe gee, "maar steeds getrou bly aan die bedoelings en insigte wat dit gemotiveer het" (J. \& C. Kriel, kyk Muller, 2002:135).

Goeie intensies alleen is egter nie voldoende nie; die Nuwe Hervorming staan voor die groot uitdaging of dit die toets van lewensvatbaarheid, vrugbaarheid en volhoubaarheid kan deurstaan (Matt. 7:15-20; 1 Kor. 3: 14). Hierby kom dat woorde draers is van betekenisinhoude; dit is uiters verwarrend om voort te gaan om steeds dieselfde woorde te gebruik (bv. oor die opstanding) maar die betekenisse daarvan radikaal te verander. ${ }^{11}$

Die vraag is nou: wat leer die Nuwe Hervorming ten opsigte van God, van Jesus, van die kerk, van die eskatologie en van die Bybel? Het ons hier te doen met 'n outentieke herformulering van die Christelike geloof of nie, met hervorming of misvorming, met reformasie of deformasie, ja, met verwagting of verydeling?

\section{Godsleer en panenteïsme}

Ek begin doelbewus met een van die mees fundamentele vrae in die Christelike geloof en dit is die vraag na God. Met hierdie vraag begin ook Calvyn sy beroemde Geneefse Kategismus, naamlik: Wat is die belangrikste doel van die mense se lewe? En die antwoord: Om God te leer ken deur wie die mens geskape is. Wie in die Godsleer dwaal, sal baie moeilik die ander dele van die Christelike geloof orent kan hou.

Wat leer die Nuwe Hervorming oor God en wáárom word hierdie nuwe benadering voorgestaan? Dit is duidelik dat die Godsbeeld en die wêrelbeeld vir die Nuwe Hervorming ten nouste saamhang. Soos Piet Muller (aan Hanlie Retief - Beeld, 10 Maart 2002, p. 12) gesê het: "As jou wêreldbeeld verander, verander alles". Die onderskeiding tussen 'n premoderne, moderne en postmoderne wêreldbeeld speel inderdaad in die Nuwe Hervorming 'n deurslaggewende rol (vgl. Craffert, kyk Muller, 2002:70-79). "Feitlik al die fundamentele begrippe van die Christelike

11 Vergelyk Wolmarans se opmerking in Beeld (19 Aug. 2002) dat dit onwaar is dat die Nuwe Hervorming Jesus se maagdelike geboorte en opstanding ontken; "wat ons wel probeer doen, is om dié sake in hul antieke konteks te lees en akkuraat te interpreteer." 
geloof het [vanweë die moderne wêreldbeeld] in die gedrang gekom" (J. \& C. Kriel, kyk Muller, 2002:137).

Die Godsleer speel veral in die denke van Wolmarans'12 'n belangrike rol, hoewel dit vir die ander Nuwe Hervormers ook belangrik is. Wolmarans oordeel dat die tyd vir 'n nuwe godsbeeld aangebreek het (Beeld, 17 April 2002, p. 13). By Israel kry ons byvoorbeeld te doen met 'n oorlogsgod wat brutaal en moorddadig aan die kant van sy mense veg. Die probleem word goed verwoord in die volgende uitspraak van Gideon Nel van Bloemfontein: Ek kan nie langer glo "soos die Kerk van my verwag om te glo nie: in 'n knoeiende God, 'n wraakgierige God, 'n jaloerse God, 'n onregverdige God, 'n besluitlose God, 'n wrede God" (aangehaal deur Muller, 2002:20).13

In die lig van die postmoderne wêreldbeeld moet ons God nie (net?) meer as persoon voorstel nie en behoort die teïstiese Godsbeeld met 'n panenteïstiese Godsbeeld vervang te word, dit wil sê God is alles in almal en alles en almal is in God (Wolmarans, kyk Muller, 2002:223; Wolmarans, 2002d:16; ook Craffert, kyk Muller, 2002:83). Die teïstiese, persoonlike, bonatuurlike Godsbeeld is uitgedien; "om aan God te dink as 'n goddelike supermens (teïsme) is nie meer aanvaarbaar nie" (Muller, 2002:12-13).

Hierdie panenteïstiese Godsbeeld word dan deur Wolmarans (kyk Muller, 2002:65-66) ten opsigte van Psalm 23 soos volg uitgewerk: In plaas van Die Here is my herder word dit nou: Die aarde versorg my soos 'n herder, met as slot: Ek weet, solank ek lewe / sal die aarde vir my sorg. / Daarom is ek tuis in die heelal / nou en vir altyd.

Binne hierdie konteks kry die klassieke voorsienigheidsleer ook nuwe betekenis. "Ons kry 'n beeld van God wat binne die skepping met weerspannige materiaal werk om iets positief tot stand te bring. God gryp nie 'van buite af' in die skepping in nie" (Wolmarans, 2002d:16; Muller, 2002:13). Die teologie van God se ingryping moet vervang word met 'n teologie van menslike verantwoordelikheid (Wolmarans, kyk Muller, 2002:223). (Die kritiese vraag ontstaan of ons nie hier te doen het met 'n

12 Vergelyk die debat tussen König en Wolmarans in Beeld van 18 en 30 April en 2 Mei 2002. Vergelyk König (2002b:288): "Die feit dat daar navorsers is wat meditasie teenoor gebed stel, beteken dat hulle 'n ander God teenoor die Vader van Jesus stel." Vergelyk ook die kritiek van G. van Wyk (2003:6) teen Wolmarans se Godsleer.

13 Dit is blykbaar 'n wydverspreide ervaring, vergelyk Yancey (2001:6): "Although I heard that 'God is love' the image of God I got from sermons more resembled an angry, vengeful tyrant." 
uitermate optimistiese mensbeeld nie waar die harde realiteit van die sonde kwalik ter sprake kan kom.)

'n Volgende vraag wat ontstaan, is of daar binne hierdie nuwe Godsbeskouing nog ruimte vir gebed is. Die antwoord is nee. Die aard van die gebed moet verander van lofgebed na meditasie (soos Funk gesê het) (Muller, 2002:13). Gebed as versoek moet vervang word met gebed as luister of meditasie (Wolmarans, kyk Muller, 2002:223; Wolmarans, 2002d:16, 17; vgl. J. \& C. Kriel, kyk Muller, 2002:158).

Die vraag is nou hoe ons oor hierdie panenteïstiese Godsbeeld moet oordeel - 'n Godsbeeld wat baie sterk herinner aan dié van die prosesteologie van A.N. Whitehead en J.B. Cobb. Sou 'n mens jou vir hierdie benadering dalk op Calvyn kon beroep waar hy opmerk dat 'n mens die bewering "dat die natuur God is" (waarskynlik oorspronklik van Zwingli) wel "met eerbied kan gebruik mits dit uit 'n vroom gemoed spruit"? Calvyn voeg egter onmiddellik by dat dit 'n "growwe (en) onpaslike bewering is om God en skepping te verstrengel" (Inst. 1.5.5). Uit sy ganse teologie blyk afdoende dat hy duidelik tussen Skepper en skepping onderskei.

Maar is dit dan nie waar dat Christelike teoloë, as 'n soort middeweg tussen deïsme en panteïsme, met die idee van panenteïsme begin eksperimenteer nie?14 Ons vind die uitdrukking byvoorbeeld by Moltmann (1980), by Veenhof (1990:92)15 en by Van de Beek (1996:261). Van de Beek wys daarop dat die begrip panenteïsme sowel positief (siende op God se alomteenwoordigheid) as negatief geïnterpreteer kan word (vgl. byvoorbeeld die prosesteologie, waar die onderskeid tussen God en wêreld verdwyn).

Dit is natuurlik eg Bybels om te sê, soos Paulus vir die Griekse wysgere in Atene, dat ons "in" God lewe, beweeg en bestaan (1933/1955vertaling) (1983-vertaling bevat "deur") (Hand. 17:28) en dat God eenmaal alles "in" almal sal wees (1933/1955-vertaling) (1983-vertaling bevat "vir") (1 Kor. 15:28). God woon deur sy Heilige Gees in mense se harte en Hy werk deur sy Gees in die skepping. Vir Paulus is daar egter geen sprake van 'n vervloeiing van die grens tussen die Skepper en die

14 Ook by H.M. Kuitert (2000) verdwyn die persoon-wees van God. Vir 'n deeglike bespreking van Keith Ward se beskouings, vergelyk Potgieter (2002). Potgieter (2002:242 e.v.) soek 'n Christologiese oplossing vir die immanensie van God, terwyl Van de Beek (1996:259-263) die Pneumatologie hiervoor aanwend. Ook Du Plessis (2003:74-76) werk met die begrip panenteïsme. Stoker (1970:9-17) wys panenteïsme skerp af.

15 "Perzoonlik ben ik van mening, dat de panentheïstische gedachtenlijn een vruchtbare en veelbelovende aanzet vormt ..." 
skepping nie. God het die wêreld met alles wat daarin is gemáák, sê hy (Hand. 17:24). Deur die ganse Bybel, Ou sowel as Nuwe Testament, is dit 'n onopgeefbare belydenis: God en sy skepping val nie saam nie en vloei nie ineen nie. Hierdie onderskeiding vorm die grondslag van die Christelike gebed.

Die God van die Ou Testament is natuurlik geen ander God as dié van die Nuwe Testament nie (soos Marcion in die tweede eeu n.C. beweer het). Die God van Abraham, Isak en Jakob is geen ander God as die Vader van Jesus Christus nie.16 Reeds in die Ou Testament gaan dit basies oor die genadige, barmhartige en liefdevolle God wat mense wil réd, Israel en die nasies. Dit is 'n deurlopende tema in die Ou Testament, van die begin af (Eks. 34:6), deur die Psalms (78:38; 86:15; 105:8; $111: 4 ; 112: 4 ; 145: 8$ ), by die profete (Hos. 2:18; Joël 2:13; Jona 4:2) en tot die einde toe (Neh. 9:17). Trouens, hierdie belydenis van God se fundamentele goedheid was deel van Israel se liturgie!

Die probleem is nie geleë in die goedheid van God nie, maar by die ongehoorsaamheid en onvermoë van Israel om hierdie goedheid van God te verkondig en uit te leef. Nou, na die koms van Jesus Christus, as uitdrukking van God se onpeilbare liefde vir die wêreld (Joh. 3:16), is daar geen verskoning meer dat God nie as die goeie God (Luk. 18:19) en die God van liefde (1 Joh. 4:8) geken en erken sal word nie. Die hele boodskap van Jesus Christus kan immers in 'n enkele sin saamgevat word: "God is lig, en daar is (hoegenaamd!) geen duisternis in Hom nie" (1 Joh. 1:5). Dat mense Hom nou nog as wreed en wraakgierig ervaar, is 'n geweldige aanklag teen die predikers van die kerk. Uiteraard word hiermee nie ontken dat God ook toorn oor die sonde en boosheid in die wêreld en eenmaal sy regverdige oordeel daaroor sal uitspreek nie.

Vir 'n panenteïstiese benadering, waar God so deel word van sy skepping, en sy skepping so deel word van Hom dat daar tussen albei eintlik geen onderskeid meer is nie, en daarom ook geen plek vir die gebed as aanbidding, lofprysing en danksegging nie, waar God dus nie meer persoonlik aangeroep kan word nie, is daar in die Bybelse boodskap geen plek nie. As God nie meer Gód is nie, kan die mens nie meer mens en die wêreld nie meer wêreld wees nie. Anders gesê: ons Godsbeeld is nie van ons wêreldbeeld afhanklik nie, maar ons wêreldbeeld van ons Godsbeeld. Dít, lyk my, is die essensie en intensie van die eerste en tweede gebod.

Ten slotte: as God nie meer die Skepper is nie wat, wanneer nodig, op 'n bonatuurlike wyse kan ingryp in die wêreldgeskiedenis en wêreldgebeure

So tereg by Botha (kyk Muller, 2002:187, 189.) 
nie, is Hy dan nog Gód, of het Hy 'n magtelose slagoffer en gevangene geword van sy eie onbeholpe planne en dade, lemand dus wat op ons as mense moet wag om ons "menslike verantwoordelikheid" op te neem en die wêreldchaos te orden? Die Godsleer van die Nuwe Hervorming gaan uit van 'n geslote wêreldbeeld, en dit in 'n tyd dat ruimtereise en makroteleskope die wonderwêreld van die heelal al hoe meer ontsluit.

\section{Christologie of Jesulogie}

Een van die swaartepunte van die Nuwe Hervorming word in die (wat in die klassieke dogmatiek genoem word) Christologie aangetref, waar daar inderdaad 'n fundamentele herinterpretasie plaasvind en waar, bewustelik of onbewustelik, sterk aansluiting gevind word by Rudolf Bultmann se ontmitologiseringsprogram. 17 Feitlik elke aspek van die Christologie en verlossingsleer word geherinterpreteer: die inkarnasie, die wonders, die kruisdood (as soenoffer) en die opstanding. "Die uitdaging is om hierdie verhale as mites te verstaan en akkuraat oor die betekenis daarvan te praat" (Wolmarans, kyk Muller, 2002:212). Die wyse waarop die evangelie - die goeie boodskap aangaande Jesus - verstaan en aangebied word, is onversoenbaar met die moderne wêreldbeeld en Bybelwetenskap (J. \& C. Kriel, kyk Muller, 2002:134).

Die "tradisionele siening van verlossing is nie die beste manier om die Christelike tradisie te verwoord nie" (Craffert, Beeld, 20 Mei 2002, p. 5). Wolmarans (2002c) kan daarom aanvoer dat dit "onwaar" is dat die Nuwe Hervorming die maagdelike geboorte van Jesus en die opstanding ontken, "wat ons wel probeer doen, is om dié sake in hul antieke konteks te lees en akkuraat te interpreteer" (Beeld, 19 Aug. 2002). Die vraag is egter of hierdie herinterpretasie van die Christologie reg laat geskied aan, eerstens, die weergawe daarvan deur die vroegste oor- en ooggetuies van die Christusgebeure en, tweedens, aan die geloofsverstaan daarvan deur Christene oor 'n periode van twee duisend jaar - waaraan ons later sal aandag gee.

"Ons weet", sê die Kriels (kyk Muller, 2002:139), "dat maagdelike geboortes nie biologies moontlik is nie. Mense kan nie op water loop nie, uit die dood opgewek word of opvaar hemel toe op wolke nie". Mense wat nie meer tradisioneel glo nie, is nie ongelowig of domastrant nie, "maar gewoon getrou aan basiese wetenskaplike insigte - Dalk moet

17 Vir 'n kort bespreking, met verwysings, vergelyk Van Wyk (2002b:607-612). Vergelyk in hierdie verband Bultmann (1969:24) se bekende uitspraak: "Dit is onmoontlik om elektriese lig en 'n radio te gebruik asook moderne mediese en kliniese middele vir siekes aan te wend, en terselfdertyd te glo aan die Nuwe-Testamentiese wêreld van geeste en wonders." 
hierdie verhale oor Jesus dan nie verstaan word as historiese feite nie maar as kultuurgebonde interpretasies van sy lewe en visie" (J. \& C. Kriel, kyk Muller, 2002:139). Waar Botha (kyk Muller, 2002:179-183) (tereg) aandag vra vir die Joodse agtergrond van Jesus, 18 oordeel Wolmarans (kyk Muller, 2002:220) dat die Bybelskrywers "die historiese Joodse Jesus in terme van die Helleense misteriekultusse geïnterpreteer het". "Jesus is in terme van die bekende Helleense heldepatrone geïnterpreteer om Hom aanvaarbaar te maak vir mense uit 'n heidense milieu" (Wolmarans, 2002d:17). 19 "Met die oorgang van die Christendom vanaf 'n Joodse sekte tot 'n Grieks-Romeinse godsdiens is die lewe en dood van Jesus toenemend binne die raamwerk van die Griekse heldelewe geplaas" (Muller, 2002:14, 17). Opvallend is egter dat Craffert (kyk Muller, 2002:164-175) sowel die benadering van die Ortodoksie (Jesus as bonatuurlike wese) as dié van die Jesus-Seminaar (Jesus as wysheidsleraar in mitologiese kleed) afwys en kies vir 'n kultuursensitiewe benadering van Jesus.

Oor die algemeen gesproke maak die Nuwe Hervorming 'n skerp onderskeid tussen die "historiese Jesus" en die "verkondigde Jesus" - soos ook by Bultmann en Crossan aangetref word. Die "dogmatiese Jesus" (van die belydenisskrifte van die kerk) kan nie gelykgestel word aan die "historiese Jesus" nie (Spangenberg, 2002b; Rapport, 23 Junie 2002). Die beeld van die "historiese Jesus" hou verband met die beeld van die "vertelde Jesus" maar is nie presies dieselfde nie (Spangenberg, kyk Muller, 2002:99).

Die vraag is nou: watter implikasies hou hierdie herinterpretasie van die Jesusverhale vir die (klassieke) Christologie in?20 Ons bespreek slegs drie daarvan: die kruisiging, die hellevaart en die opstanding.

Wat die kruisiging van Jesus betref: binne die denkraam van die Nuwe Hervorming word dit nie meer verstaan as 'n soenoffer vir ons sondes (vgl. Hebreërs) of as vergewing van ons sondes teen God (vgl. Romeine) nie. Jesus is gekruisig as slagoffer van sosiopolitieke onderdrukking

18 Vergelyk hieroor Van de Beek se jongste boek (2002:37-46).

19 Vergelyk in hierdie verband die standpunt van die groot Duitse liberale teoloog Adolf von Harnack (1851-1930) : "Das Dogma ist in seiner Conception und in seinem Ausbau ein Werk des grieschischen Geistes auf dem Boden des Evangeliums" (Von Harnack, 1931:20; vgl. veral ook Von Harnack (1903) en Wentsel, 1998:120). Vergelyk die volgende uitspraak van Bonhoeffer: "Dogmatisch gesehen war Harnack ein Irrlehrer" (by Rothuizen, 1969:193).

20 Vergelyk hier ook die nuwe "Christologie" van Van Aarde (2001:401-417), waarmee die Ou-Testamentikus Le Roux (2002:77-99) volledig saamstem. Vir 'n bespreking van verskillende Jesusbeelde, vergelyk onder andere Den Heyer (1996). 
(Botha, kyk Muller, 2002:191). Hy is nie veroordeel omdat hy die ewige lewe verkondig het nie, maar implisiet omdat hy gesê het die ewige lewe beteken om verantwoordelikheid vir 'n mens se naaste te aanvaar (kyk Luk. 10:27-37)21 (Botha, kyk Muller, 2002:192). Jesus is nie gekruisig omdat hy geleer het dat hy die Seun van God is nie, maar omdat hy geleer het 'n sekere lewenswyse is belangrik (nl. anti-patriargie); hy het nie ontologiese uitsprake oor God gemaak nie, maar gewys op die etiese implikasies van die Godsheerskappy (Botha, kyk Muller, 2002:195).

Die gedagte van die soendood van Jesus rus op 'n uitgediende offersisteem; dit is "problematies", "primitief" en "uitgediend" (Wolmarans, kyk Muller, 2002:223; Wolmarans, 2002d:17,1 8). In 'n postmoderne wêreld is die slag van offerdiere iets primitiefs en word die soenoffer van Jesus onbegrypliker en onaanvaarbaarder (Muller, 2002:14)22. Vergifnis word ontvang deur dit te gee.

Die probleem met hierdie herinterpretasie is dat Jesus (en die Nuwe Testament) nie meer as die kulminasie en vervulling van die $\mathrm{Ou}$ Testament gesien kan word nie en dat die interpretasie van die kruisgebeure deur byvoorbeeld Paulus en Hebreërs moet verval.

Oppervlakkig beskou lyk dit of die hellevaart23 van Jesus nogal steun verleen aan die standpunt van die Nuwe Hervorming. Immers, "as ons die hellevaart ontmitologiseer, hoekom kan ons dit nie ook met ander artikels in die geloofsbelydenis doen nie?" (Wolmarans, 2002b; Beeld, 28 Mei 2002). In hierdie argument word twee belangrike aspekte egter nie verreken nie. Die eerste is die dogmahistoriese aspek, naamlik dat die artikel oor die neerdaling na die hel, wat redelik laat in die Apostolicum opgeneem is, gedurende die eerste millennium (hoogs waarskynlik) verstaan is as "neergedaal na die doderyk", wat 'n ander manier van sê was dat Christus wáárlik gesterf het (vgl. slegs Wentsel, 1991:222-232; Grudem, 1994:586-594). Die tweede is dat, in teenstelling tot die herhaaldelike en duidelike verwysings na die opstanding van Jesus, daar in die Nuwe Testament slegs enkele en moeilik verklaarbare tekste met die hellevaart in verband gebring kan word. Die gedagte van 'n reële

21 Die vraag ontstaan hier: hoe weet ons (op die standpunt van die Nuwe Hervorming) of Lukas 10 outentieke woorde van Jesus bevat?

22 Ook "Crossan deel nie die siening dat Christus [Jesus?] gekom het om aan die kruis ter wille van mense se sondes te sterf sodat hulle hemel toe kan gaan nie" (Jackson, 2002b). Vergelyk hier die kommentaar van König (2002a:15).

23 Dit wil voorkom asof Piet Muller totaal onbewus is daarvan dat die belydenis aangaande die neerdaling na die hel al vir langer as vier eeue in die reformatoriese kerke nie "letterlik" vertolk is nie; vergelyk HK 16:44. Vergelyk sy opmerking dat "al minder kerke glo byvoorbeeld dat dit letterlik verstaan moet word" Muller (2002:11). 
hellevaart, soos byvoorbeeld in die Katolieke tradisie verstaan, gaan mank aan Skriftuurlike substansiëring. Vandaar dat Calvyn hierdie artikel "ontmitologiseer" het (Inst. 2.16.8-13).

Kom ons by die opstanding van Jesus, dan het ons te doen met een van die hartare van die evangelie en van die Christelike geloof.24 Die vraag is naamlik: moet die opstanding van Jesus ook in terme van die premoderne mitologiese wêreldbeeld verstaan word sodat - volgens die Nuwe Hervorming - bely moet word dat Jesus nie wáárlik liggáámlik uit die dood opgestaan het nie? Die Nuwe Hervorming se antwoord is 'n onteenseglike ja. Hy hét nie, Hy kón nie liggaamlik opgestaan het nie, omdat soiets wetenskaplik onmoontlik is. Hoe moet die Bybelse verhale oor sy opstanding dan verstaan word? Volgens die Nuwe Hervormers só: dat sy dissipels geglo het dat Jesus se visie, sy lewenswyse in hulle lewe voortgesit word; hulle wou in hulle wêreldbeeld en met hulle begripsapparaat te kenne gee dat Jesus se saak nie by die kruis opgehou het nie, maar dat Hy in hulle werk en moeite sigbaar is (Botha, kyk Muller, 2002:193). "Dis verkeerd om die opstanding as 'n 'liggaamlike opstanding' te verstaan" (Craffert, volgens Jackson in Beeld, 12 Maart, 2003, p. 11). Jesus se volgelinge het in samekomste sy bemagtiging en teenwoordigheid ervaar. "In daardie sin het hy vir hulle 'opgestaan uit die dood'" - iets wat metafories verstaan moet word (J. \& C. Kriel, kyk Muller, 2002:155). ${ }^{25}$ As ek die interpretasies van die Nuwe Hervorming hier reg begryp, dan beteken dit dat Jesus voortleef in die harte van sy navolgers soos wat Karl Marx voortleef in die harte van sy Marxistiese navolgers. Van 'n lewende verhouding met 'n lewe in Jesus

24 Ook Ben du Toit, in sy opspraakwekkende boek oor God, sien nie kans om die wonder van die opstanding te laat vaar nie (Du Toit, 2000:150-153, 160). Hoewel Du Plessis (2003:125) sterk aansluit by Craffert se kultuursensitiewe interpretasie, kon hy hierdie benadering nie ten opsigte van die opstanding van Jesus volhou nie en probeer hy tussen fundamentalisme en rasionalisme deurstuur; Jesus "het fisiek opgestaan" (Du Plessis, 2003:139). Vergelyk König (2001:156): "ons geloof staan of val selfs met die opstanding van die liggaam"; Du Rand (2001:52): "Die historiese opstanding van Jesus van Nasaret raak die wesenlike van ons geloof. 'n Mens kan sê dit bepaal ons geloof"; Van de Beek (2002:45): "Zonder opstanding geen christendom." Ook Berkhof (1990: $305)$ is van mening: "Daarom staat en valt het christelijk geloof met de opstanding." Onlangs het Wentzel van Huyssteen (by Gaum, 2003:12) dieselfde mening ten opsigte van die Nuwe Hervorming gelug: "So is dit byvoorbeeld met die opstanding van Jesus Christus. As die teologie dít wil ontken, tas die teologie die Christelike geloof in sy kern aan en gaan die teologie óór die grens ... Al wat ek wil vra is: Wat is nou eintlik nuut daaraan?" Kyk J.H. van Wyk (2000:23).

25 Vergelyk hier die standpunt van Bultmann (1969:69): "Naas die historiese feit van die kruis staan die verrysenis, wat geen historiese gebeure is nie." Vir die debat oor die opstanding wat in Nederland gevoer is, vergelyk Van Gennep et al. (1989). Ook J.A.T. Robinson (1967:34-37) verwerp die liggaamlike opstanding. 
Christus kan daar net so min sprake wees as van 'n lewende verhouding met 'n lewende Marx - want albei is dood. 26

Die opstanding kan as "simbool van vernuwing en vooruitgang funksioneer" (Wolmarans, kyk Muller, 2002:65); dit beteken "dalk dat die goeie sal seëvier" (Wolmarans, 2002b in Beeld, 28 Mei 2002); dat God (sic!) se liefde en geregtigheid deurbreek ten spyte van vervolging en weerstand (Wolmarans, kyk Muller, 2002:223).

As daar egter een plek is waar 'n ekstreme aanwending van die wêreldbeeld-model aan flarde spat, dan is dit hier sigbaar waar oor die opstanding van Jesus gehandel word. Dit is juis 'n konteks- en kultuursensitiewe benadering wat in hierdie opsig 'n belangrike bydrae lewer.27 Die vraag oor die liggaamlike opstanding is immers nie 'n moderne vraagstelling nie, al het die Aufklärung van die agtiende eeu dit verskerp. Die vraag na die opstanding was reeds 2000 jaar gelede in dáárdie konteks en kultuur net so aktueel (en problematies) soos vandag, sowel in die Joodse teologie as in die Griekse filosofie. Dit is bekend dat die "ortodokse" Fariseërs die opstanding uit die dood aanvaar het terwyl die "liberale" Sadduseërs dit afgewys het (Hand. 23:8). In die Griekse filosofie het Plato die onsterflikheid van die siel aanvaar, maar daarmee saam die sterflikheid en verganklikheid van die liggaam, terwyl Stoa en Epikurus sowel die sterflikheid van die siel as dié van die liggaam aanvaar het. En dit is juis met laasgenoemdes dat Paulus in Atene swaarde kruis en 'n gewillige gehoor vind, tot die gesprek op die punt van die liggaamlike opstanding afspring (Hand. 17:32). Waarom sou Paulus hom so uitgeput het om juis aan 'n Griekse gemeente so 'n lang brief oor die liggaamlike opstanding te skryf (1 Kor. $15)$ as hy dit vir homself en die gemeente soveel makliker kon gemaak het deur gewoon te sê: kom ons verstaan die opstanding metafories, dan is alle probleme uit die weg geruim? Of kom ons verstaan die opstanding op spiritualistiese wyse (identies aan wedergeboorte), soos Himeneus en Filetus en die gnostieke denkers dit verstaan het (2 Tim. 2:17-18), dan maak ons dit vir almal soveel makliker? Paulus, en die Nuwe Testament, doen dit egter nie, maar handhaaf konsekwent die opstanding/opwekking van Jesus as onopgeefbare deel van die evangelie. Dit is nie iets wat terloops in die Nuwe Testament verkondig word nie, maar vorm een van die wesenskenmerke van die apostoliese prediking. As daar één ding is

26 Vergelyk hier die Kriels (kyk Muller, 2002:150, 152) se verwysing dat volgens Romeinse gebruik Jesus se liggaam aan die kruis gelaat sou word vir roofvoëls, of in 'n vlak graf met gebluste kalk gegooi sou word (vgl. Crossan).

27 Daar moet myns insiens ten minste drie kontekse verreken word: (1) die teologiese konteks van 'n teks, (2) die kultuurhistoriese konteks van destyds en (3) die kultuurhistoriese konteks van vandag. 
wat Timoteus moet onthou, dan is dit dít: "Onthou altyd dat Jesus Christus, 'n nakomeling van Dawid, uit die dood opgewek is. Dit is die evangelie wat ek verkondig" (2 Tim. 2:8). So ook Romeine 10:9: "As jy met jou mond bely dat Jesus die Here is, en met jou hart glo dat God Hom uit die dood opgewek het, sal jy gered word." Daar is in die Nuwe Testament nêrens, maar nêrens, selfs die geringste indikasie om die opstanding/opwekking van Jesus bloot simbolies of metafories te verstaan nie. Ongetwyfeld word aan die opstanding 'n geestelike betekenis geheg (Rom. 6:8-11; Ef. 2:4-7), maar dan word dit gedoen juis op grond van die liggaamlike opstanding/opwekking (vgl. ook HK 17:45).

Wat die veranderende wêreldbeelde betref: naas die feit van diskontinuïteit tussen die voorwetenskaplike en die wetenskaplike wêreldbeeld, waarop die Nuwe Hervorming tereg wys, bestaan daar ook 'n bepaalde kontinuïteit, wat deur die Nuwe Hervorming onderspeel of eintlik ontken word. Daar is aspekte van die wêreldbeeld wat verander terwyl ander aspekte onveranderd bly. So praat ons as (post-)moderne mense vandag nog van die son wat "opkom" en "ondergaan" en nie van die aarde wat om die son draai nie. Saamgevat: daar bestaan nie net die denkmodel van naïewe realisme nie maar ook dié van naïewe kritisisme. Onder naïewe kritisisme verstaan ek daardie teologiese denkmodel waar (naïef) van die voorveronderstelling uitgegaan word dat wanneer "moderne wetenskaplike en teologiese navorsing" as hermeneutiese sleutel vir Skrifverstaan aangewend word, dit noodwendig tot 'n juiste (of beter) verstaan van die Bybel sal lei.

Dit val op dat die Nuwe Hervorming byna deurgaans van Jesus praat en wegskram van die woord Christus (en Here), hoewel hulle tog ook weer van "Christene", van "Christelike geloof" en van die "Christendom" praat. Die Kriels (kyk Muller, 2002:138) het (tereg) "begin wonder of ons ons nog Christene kan of mag noem", om uiteindelik te antwoord dat hulle hulself nog "tuisvoel binne die breë Christelike tradisie en beskou ons (ons) steeds as volgelinge van Jesus van Nasaret en as 'toegewyde Christene'" (kyk Muller, 2002:156) - 'n problematiese stelling waarop ons later terugkom. Gesien die interpretasie wat die Nuwe Hervorming van die persoon en werk van Jesus daarop nahou, is dit, teologies gesien, 'n enorme probleem of hier nog van Christologie gepraat kan word en of ons nie eerder van Jesulogie moet praat nie. En by implikasie ook nie meer van "Christene", soos in die klassieke sin van die woord nie (Hand.11:26), maar eerder van "Jesuïete" of "Jesus-mense", soos Wolmarans (2002a:13) dit stel (Beeld, 17 April 2002:13).28

28 Die volgende opmerking van Craffert (Die Kerkbode, 14 Okt. 2002, p. 5) is dubbelsinning: "Na my wete ontken geen lid van die gespreksgroep die Godheid van 
Waar die persoon en werk van Jesus totaal anders verstaan word, kom die hele verlossingsleer ook in gedrang. Sal die Nuwe Hervorming my verkwalik indien ek hulle interpretasie van verlossing só verstaan dat dit in die mens self geleë is? Die Nuwe Hervorming "reik nie na verlossing eendag nie, maar streef om hemel hier op aarde te help bewerkstellig" (Craffert, kyk Muller, 2002:86). Muller (2002:231) verwys hier na die Evangelie van Tomas (vers 70): "As julle voortbring wat in julle is, sal dít wat julle voortbring julle red" (kyk ook Meyer, 1992). Verlossing word hiervolgens ' $n$ deur en deur menslike saak en rus nie meer op die genade van God in Christus wat in geloof omhels moet word nie.

Dit is duidelik: die Nuwe Hervorming "verkondig inderdaad 'n ander weergawe van die Christelike geloof" (Craffert, Beeld, 18 Sept. 2002, p. 13). Die vraag is: is dit nie 'n ander "evangelie" nie?

In die sestigerjare van die vorige eeu kon die God-is-dood-teologie nie langer as 'n dekade oorleef nie; dit is moeilik om in te sien dat 'n Jesusis-dood-teologie enigsins lewensvatbaar kan wees.

\section{Ekklesiologie: koinonia of skisma}

Oor die ekklesiologie is daar relatief min besin in die Nuwe Hervorming. Hang dit saam met die feit dat (sommige van) hulle nie direk by kerklike vergaderings betrokke is nie, dalk min in gemeentes preek; saamgevat, teologie in isolasie en nie in konkrete kerklike gemeenskap beoefen nie?

Die kerk word gesien as 'n oop gemeenskap sonder enige diskriminasie hoegenaamd (Wolmarans, kyk Muller, 2002:224). Oor die spesifieke betekenis en belangrikheid van die doop kon ek niks vind nie, maar 'n nuwe visie op die Nagmaal is wel duidelik: soos wat koring- en druiwekorrels voedsame brood en wyn word, so kan gelowiges die lewe se beproewings en teenslae op 'n positiewe manier hanteer (Wolmarans, kyk Muller, 2002:222).

My konklusie aangaande die sienings van die Nuwe Hervorming is: aangesien Christus nie liggaamlik opgestaan het nie, kan daar dus nie daarvan sprake wees om tydens die Nagmaalviering die harte na die hemel na die lewende Jesus Christus op te hef nie; die Nagmaal word gereduseer tot 'n blote herinneringsmaal aan die dood van 'n voortreflike mens. Terwyl die ortodokse Christen sy/haar hart "ophef" na die lewende Jesus Christus, sal die Nuwe Hervormer in sy hart "terugdink" aan die lewe en dood van 'n goeie mens Jesus.

Jesus nie. Die vraag is wat daarmee bedoel word." Hoe kan die Godheid van Jesus volgehou word indien sy liggaamlike opstanding ontken word? 
En wat die prediking betref: die Nuwe Hervormers laat hulle nie uit oor die vraag hoe hulle die evangelie in 'n premoderne gemeente in MiddeAfrika, met 'n ongeletterdheidsyfer van meer as $90 \%$, sal (probeer) preek nie. Is dit hoegenaamd moontlik om, op die teologiese basis soos uiteengesit deur die Nuwe Hervorming, die evangelie van God se genade in Christus nog te preek? Die vraag dring homself na vore: préék die teoloë van die Nuwe Hervorming nog in gemeentes?

Dit sal vir die Nuwe Hervormers seker moontlik wees om, tydelik altans, nog steeds eredienste by te woon, al word baie van die dinge wat gedoen en gesê word anders as die res van die gemeente verstaan; so sal dit ook moontlik wees om - tydelik - Kersfees en Paasfees in terme van die geboorte- en lydensverhale te vier, nie as historiese verhale nie, maar as mites (J. \& C. Kriel, kyk Muller, 2002:157). Op die lange duur kan so 'n benadering egter nie bevredig nie, want ander gelowiges sal die Nuwe Hervormers as dwaalgeeste beskou (en as sodanig dissiplineer), terwyl die Nuwe Hervormers die ander gelowiges vir primitief, premodern en onvolwasse sal aansien. Uiteindelik moet dit óf op kerkskeuring uitloop óf op vleuelvorming binne die een kerkverband, soos gebeur het in die Hervormde Kerk in Nederland waar drie groepe ontstaan het: die vrysinniges (links), die Gereformeerde Bond (regs) en die Midde-Ortodoksie (middel).

Wat duidelik is, is dat die klassieke interpretasie van die Christelike geloof en die herinterpretasie daarvan deur die Nuwe Hervorming in hoogspanning met mekaar verkeer en, sover ek sien, nie sáám kan bestaan as outentieke interpretasies van die evangelie van genade nie.

\section{Eskatologie: hiernamaals as hiernoumaals}

Dat die klassieke leer oor die eskatologie ook in die Nuwe Hervorming ingrypend hersien sou word, spreek eintlik vanself. Dit is waar dat die hooftema in die prediking van Jesus, naamlik die koninkryk van God, (tereg) 'n besondere aksent in die Nuwe Hervorming ontvang. Die Nuwe Hervorming sien dit so dat Jesus 'n koninkryksbeweging begin wat die status quo van sy tyd bedreig; hy preek dat God mense wysheid gegee het om só te lewe dat God se heerskappy en krag op aarde sigbaar word (volgens Crossan)(J. \& C. Kriel, kyk Muller, 2002:148, 149). Jesus verkondig die koninkyk van God, wat beteken 'n bekering van die Romeinse en kosmiese magte na die mag en heerskappy van God (Botha, kyk Muller, 2002:187).

Die dimensies van individuele en universele toekomsverwagting word egter in die Nuwe Hervorming krities bevraagteken. Immers, "nuwe navorsing toon ook dat wanneer die Bybel oor die hiernamaals praat, dit 
maar eintlik 'n ander manier is om oor die hiernoumaals te praat" (Wolmarans, 2002d:16). Botha het by geleentheid opgemerk dat hy tevrede is daarmee dat die mens 'n eenheid is "en dat hy self heeltemal sal ophou bestaan die dag as hy doodgaan" (vgl. Jackson, Beeld, 20 Mei 2002, p. 5). Met die dood word "bewuste lewe beëindig" (Craffert, kyk Muller, 2002:84).29

Dit is duidelik dat, as die liggaamlike opstanding van Jesus Christus ontken word, die persoonlike toekomsverwagting (noodwendig moet) verdwyn (1 Kor. 15:19). 30

En die universele eskatologie dan? Kom daar wérklik 'n nuwe hemel en 'n nuwe aarde (2 Pet. 3:13, Op. 21:1), of is die toekoms oop, afhangende van wat die mens daarmee maak, of hoe die ewolusieproses verloop, of wat God met die weerspannige materiaal gaan uitrig? Ek kon hierop in die geskrifte van die Nuwe Hervorming geen afdoende antwoord vind nie. Wat duidelik is, is dat die eindoordeel (soos ook die sondeval), as onderdrukkende beeld(-e), ontmitologiseer behoort te word (Craffert, kyk Muller, 2002:83). ${ }^{31}$ Die vraag na, soos die toekoms self, bly egter oop. ${ }^{32}$ "Eind goed, al's goed"? - ons weet nie. Impliseer dit nie 'n duidelike ontkenning van die tema van die Christelike hoop nie (Rom. 8:24-25)?

Die eskatologiese model van die Nuwe Hervorming herinner sterk aan dié van Albrecht Ritschl (1822-1889), wat die koninkryk geïnterpreteer het as persoonlike gemeenskap met God, wat met die oog op hierdie doel 'n ononderbroke ontwikkeling van menslike aktiwiteit na morele volmaaktheid aktiveer (Willis, 1987:2). Versoening word verwerklik in die ontwikkeling van 'n nuwe etiese gemeenskap, die kerk, wat dan gerig is op die transformasie van die samelewing tot die ryk van God. Ritschl aanvaar dus (slegs) 'n immanente koninkryk wat deur menslike etiese deelname ontwikkel kan word. (Geen wonder nie dat dit die verset van sy skoonseun, Johannes Weiss, opgeroep het, wat weer die klem laat

29 Vergelyk in die verband die opmerking van Crossan: "Ek glo nie so seker dat ek dit [die hiernamaals] glo nie" (Jackson, Beeld, 17 April 2002).

30 Vergelyk in die verband die ervaring van die Duitse teoloog Ernst Käsemann (eens 'n vurige ondersteuner van Bultmann), wat tydens die Tweede Wêreldoorlog ontdek het dat hy mense by oop grafte nie met die teologie van Bultmann kon troos nie (J.H. van Wyk, 2002b:610).

31 Vergelyk in dié verband ook Craffert (2002c), waar hy die ontwikkeling van die tema van die hel verbind met spekulatiewe menslike denke.

32 Ook in die teologie van Dorothee Sölle (1993:210) bly die toekomsvraag oop; die toekoms is nie soseer in die hande van Gód nie as in dié van die méns. As ons erns maak daarmee om die bestaan van God as sosiaal te begryp, "dan hang die voortbestaan van die skepping af van die krag van die liefde onder die mense". 
val het op die toekomstigheid en bo-aardsheid van die koninkryk - maar dis 'n verhaal van sy eie.)

\section{Skrifleer en antimetafisika}

Ek het hierdie aspek doelbewus - ter wille van die debat - vir laaste gebêre, maar eintlik kon dit ook, soos in dogmatiekhandboeke gedoen word, eerste genoem gewees het. Die eintlike beslissings val reeds hier, by die epistemologie, die kenleer. Die vraag is: waar kom ons aan ons teologiese kennis? Kry ons dit deur middel van wetenskaplike navorsing, deur rasioneel-kritiese denke of ontvang ons dit in die eerste plek van God in sy Woordopenbaring? Anders gesê: as ons paaie oor die gesag, betroubaarheid en geloofwaardigheid van die Bybel uiteengaan, is die kans skraal dat ons mekaar oor die ander teologiese temas sal vind.

Dit is so dat die Nuwe Hervorming die hele Bybel as "basisdokument" van die Christendom aanvaar (Wolmarans, 2002d:18; kyk Muller, 2002: 224),33 maar dan moet die Bybelboeke "ook soos enige ander literatuur gelees word" (Spangenberg, kyk Muller, 2002:109).34 Aan die Bybel word dus geen kenteoretiese voorrang verleen nie.

Dan is daar ook nog die vraag uit hoeveel boeke die Bybel bestaan. 'n Boek wat baie sterk in die Nuwe Hervorming figureer, is die Evangelie van Tomas, wat slegs woorde, maar geen dade van Jesus vermeld nie en 'n koninkryk verkondig wat reeds in hierdie lewe bereik kan word (naamlik as gelowige geestelike heelheid) (Muller, 2002:15). Muller is baie uitgesproke dat dit juis die Evangelie van Tomas was wat hom gehelp het om van wêreldbeeld te verander (vgl. Retief, Beeld, 10 Maart 2002, p. 12; Muller, 2002:227-235).

Wat die huidige debat uiters moeilik en dikwels vrugteloos maak, is die radikale verskil in Skrifbeskouing tussen die Nuwe Hervorming en die klassieke reformatoriese tradisie. 35

Die Nuwe Hervorming is van mening dat die klassieke Skrifbeskouing die Bybel is die Woord van God - verouderd en uitgedien is (Muller,

33 Wolmarans (2002d:17) vestig die aandag daarop dat die Jakobusbrief geen melding maak van die kruisdood en opstanding van Jesus nie. Sommige verwys ook na 1 Timoteus, Filemon, 1 Petrus, 2 \& 3 Johannes en Judas.

34 Vergelyk in hierdie opsig ook ander geskrifte van Spangenberg (1995, 1998, 2002a).

35 Een van die mees Skrifkritiese artikels in die bundel, Die Nuwe Hervorming, is van die hand van Maretha Jacobs (kyk Muller, 2002:112-133). As ek haar reg verstaan, voer sy aan dat die boodskap van die Pastorale Briewe oor die vrou só misleidend is dat hierdie briewe eintlik nie as kanoniese geskrifte aanvaar behoort te word nie. 
2002:19). Sowel die fundamentalistiese Skrifbeskouing (die Bybel as diktaat) as die modernistiese (die Bybel as God se Woord in mensetaal) word afgewys; "' $n$ postmoderne siening van die Bybel is daarom meer aanvaarbaar. Dit sê die Bybel bevat mensewoorde oor God" (Wolmarans, kyk Muller, 2002:63-64). "Ons lees nie meer die Bybel as geopenbaarde en onfeilbare Woord van God nie, maar as getuienis van ons voorgangers in die Joods-Christelike tradisie"(J. \& C. Kriel, kyk Muller, 2002:157).

As gewoon godsdienstige boek bevat die Bybel "onoorbrugbare verskille" (Craffert, kyk Muller, 2002:86). Die evangelies is byvoorbeeld vol "weersprekings", "misleidings", "oordrywings", "onwaarhede" en "veralgemenings" (Botha, kyk Muller, 2002:178, 186). So is die evangelie van Johannes 'n kreatiewe skepping van die skrywer en "hy doen dit só kunstig dat lesers in sy truuk val en glo dat hy 'n ooggetuie van die [opstandings-]gebeure was" (vgl. Joh. 21:20-25) - iets wat tog onmoontlik is (Spangenberg, kyk Muller, 2002:107). ${ }^{36}$

Inspirasie beteken nie dat die tekste geïnspireer is nie, "maar kom ter sprake wanneer die teks gelees word" (Spangenberg, kyk Muller, 2002: 103).

Die rol van die moderne wêreldbeeld en moderne teologies-wetenskaplike navorsing speel 'n deurslaggewende rol in die Skrifbeskouing en Skrifverstaan. "Moderne navorsing kan 'n omvattender begrip van die gebeure ontwikkel as wat die betrokkenes gehad het " (J. \& C. Kriel, kyk Muller, 2002:147).

Kultuurhistoriese, kontekssensitiewe, wetenskaplike rekonstruksies van daardie gebeure kan vandag 'n veel omvattender en dieper insig en weergawe van daardie gebeure [oor Jesus] gee as wat toeganklik was vir die deelnemers (J. \& C. Kriel, kyk Muller, 2002:136).

Ek lei hieruit af dat (beweer word dat) moderne navorsers 'n betroubaarder beeld oor die persoon en werk van Jesus kan rekonstrueer as wat die tydgenootlike oor- en ooggetuies kon doen.

Die Nuwe Hervorming bepleit dus 'n "kultuursensitiewe benadering" van die Jesusgebeure (Craffert, kyk Muller, 2002:172-175). ${ }^{37}$

36 Volgens die Jesus-Seminaar is slegs $16 \%$ van die verhale oor Jesus, en $18 \%$ van sy woorde in die evangelies outentiek (Craffert, kyk Muller, 2002:169).

37 Dieselfde benadering word ook deur drr. F. Cronjé, J. Kirkpatrick en E. Naudé in die Kerkbode van 28 Maart 2003, p. 7 bepleit: "Ons sal saam moet leer wat kultuursensitiewe interpretasie behels en hoe 'n mens kontekstualiteit in hierdie opsig verreken." Die vraag onstaan: stem hulle saam met die standpunte van die Nuwe Hervorming? 
Waar die Middeleeuse kerk die kérk as outentieke Skrifverklaarder gehandhaaf het en die Reformasie die Bybel weer aan die gewone gelowige teruggegee het (vgl. Spangenberg, kyk Muller, 2002:89-90), daar maak die Nuwe Hervorming op sy beurt weer die Skrifverstaan afhanklik van die teologiese wetenskap en van die moderne navorsing deur vakteoloë. "Deur wetenskaplik te werk te gaan, besef ons nou dat gister se dogmas 'n valse prentjie van Jesus teken" (Craffert, Die Kerkbode, 18 Okt. 2002; my kursivering, JHvW). Anders as die naïewe en ortodokse omgang met die Bybel, gaan die Jesus-navorsing "op historiese verantwoordbare en wetenskaplik kontroleerbare wyse met hierdie bronne om" (Craffert, kyk Muller, 2002:164). Volgens Jackson (Beeld, 12 Maart 2003, p. 11) sê Spangenberg "dis inderdaad net ingeligtes wat Die Bybel kan verstaan. Die kerk kan nie Die Bybel vir mense gee sonder om hulle toe te rus om dit te verstaan nie".

Die Nuwe Hervorming gaan van die voorveronderstelling uit dat slegs 'n histories-kritiese en teologies-wetenskaplike lees van die Bybel die enigste sinvolle omgang met die Bybeltekste waarborg. Uiteraard is ' $n$ teologies-wetenskaplike ondersoek van die Bybel baie belangrik, maar as dit die (enigste) filter word vir suiwere Skrifverstaan, as daarmee geïmpliseer word dat die Bybel eintlik 'n geslote en selfs gevaarlike boek vir gewone gelowiges is, dan is ons terug in die Middeleeue waar die pous net vervang is met vakteoloë. Dan is daarmee die reformatoriese belydenis oor die claritas van die Bybel opgehef.

As ons die gedagte van God se selfbekendmaking in die Bybel prysgee, die gedagte van openbaring dus (soos wat J. \& C. Kriel, kyk Muller, 2002:142, eksplisiet doen), dan is ons baie naby aan die algehele opheffing van teologie (Woord ván God, óór God) as sodanig. Bavinck (1908:143) het hieroor 'n besonder skerp uitspraak gemaak: indien die gedagte van openbaring prysgegee word, verval ons "in 'n verderflike superstisie". Indien God nie meer as 'n persoon erken en bely word nie, dan is die konsekwensie onvermydelik: dan kan Hy ook nie meer práát nie. Maar hoe sal ons ooit weet dat Jesus die Messias en die Here is as dit nie aan ons geopenbaar en deur die Heilige Gees ingegee is nie

Hulle verklaar uitdruklik dat "die verklaring van die ASK gaan hulle [d.w.s. die soekendes] nie help nie". Die veelbesproke boek van Nel (2003) bevat heelwat prikkelende gedagtes, maar gaan soms mank aan teologiese diepgang. Hy (Nel, 2003:107) verwys byvoorbeeld enersyds na Jesus se opstanding as "die grootste nuus wat ooit in die wêreld versprei is" en dat Jesus Christus die enigste Verlosser is (2003:148, 165-177), maar andersyds verkwalik hy (Nel, 2003:101) - ter wille van 'n oop debat - 'n Ring wat spoedige optrede bepleit teen akademici/teoloë "wat uitsprake maak en standpunte handhaaf wat in stryd met die leer van die kerk is" en verwys hy positief na uitsprake van Spangenberg (Nel, 2003:149,155). In die nuwe teologiese debat word die liggaamlike opstanding van Jesus juis bevraagteken en ontken, 'n saak wat sekerlik met die grootste erns bejeën behoort te word. 
(Matt. 16:17; 1 Kor. 12:3)? Dit wil sê, indien ons Hom hoegenaamd nog as sodanig wil bely. Hoe sou Paulus ooit geweet het wat die evangelie van Jesus Christus beteken indien Jesus Christus dit nie aan hom geopenbaar het nie (Gal. 1:11-12)?

Die kritiese Skrifverstaan van die Nuwe Hervorming staan in hoogspanning met die sola Scriptura van die sestiende-eeuse Reformasie waar die Heilige Skrif as gesaghebbende en betroubare bron van Godsopenbaring aanvaar is.

\section{Evaluering}

\subsection{Waarderende opmerkings}

- $\quad$ Allereers moet daarvoor waardering uitgespreek word dat daar in die Nuwe Hervorming 'n eerlike en openhartige soeke na God is, waar verwondering (in plaas van koue logika) 'n belangrike rol speel, en waar gevra word vir deurleefde spiritualiteit, egte "Christenskap" en ware kerkwees.

- $\quad$ Verder moet waardering uitgespreek word vir die feit dat 'n proses van voortdurende reformasie vir die die kerk onontbeerlik is. Die Reformasie het geleer: ecclesia reformata semper reformanda. 'n Kerk wat stagneer en in introvertisme verval, wat pragtige kerkstrukture onderhou, wat uitwendig nog goed vertoon en selfs glad funksioneer, maar wat aan geloofs- en daadkrag ontbreek, kan kwalik nog as volk van God, liggaam van Christus en tempel van die Heilige Gees beskryf word. Die vraag is egter nie óf die kerk moet reformeer nie, maar hóé, ook en veral ten opsigte van die verstaan en herverstaan van die evangelie in wisselende kontekste.

- Waardering moet ook uitgespreek word vir die aandag wat die Nuwe Hervorming vra vir voortgestte teologiese navorsing oor die Bybel en oor die kultuurhistoriese agtergrond en konteks waarin die Bybelskrywers geleef en gewerk het en vir nuwe perspektiewe wat sodoende geopen kan word. Daar het sedert die Reformasie van die sestiende eeu 'n ontsaglike hoeveelheid Skrifnavorsing en eksegetiese arbeid plaasgevind, waarvan die resultate nog nie voldoende deur die kerk en teologie benut is nie. In die voortgaande teologiese ondersoek en debat sal ook deeglik rekening gehou moet word met nuwe insigte wat vanuit die natuurwetenskappe na vore kom (waarvoor reeds Bavinck en Berkouwer aandag gevra het [vgl. Van Wyk, 1989:54]).

- $\quad$ Dit moet ook waardeer word dat klem daarop gelê word dat die evangelie van Jesus vir (premoderne, moderne en postmoderne) 
mense verstaanbaar en sinvol vertolk behoort te word sodat dit hulle lewenswerklikheid konkreet sal betrek en transformeer. Die taak van die teologie is immers om dieselfde evangelie in wisselende kontekse telkens opnuut te formuleer sonder dat dit 'n ander evangelie word.

- $\quad$ Die volgehoue en toegewyde belangstelling in die persoon en werk van Jesus van Nasaret asook die (soms beskamende) wyse waarop $\mathrm{Hy}$ in die daaglikse lewe nagevolg word, verdien ook besondere waardering. Sonder twyfel is Jesus van Nasaret ook vir die Nuwe Hervormers iemand van besondere betekenis, veral wat sy woorde (maar ook algemene optrede) betref. Die appèl op sosiale transformasie in die samelewing moet sonder meer beaam word - "die debat gaan ten diepste oor in watter soort samelewing ons wil leef" (Craffert, Beeld, 18 Sept 2002, p. 13).

- $\quad$ Laastens wys ek daarop dat die Nuwe Hervormers, altans sommige van hulle, telkens wys op die voorlopige aard van ons menslike en dus ook teologiese kennis. So wys Jordaan (kyk Muller, 2002:59) byvoorbeeld daarop dat, "gegewe die verskeidenheid geloofsuitinge 'n mens ook versigtig moet wees om nuwe kennis, verkennings en hipoteses sonder meer aan te bied as 'n 'Nuwe Hervorming' of ' $n$ 'totale paradigmaverandering'" (vgl. ook Craffort, kyk Muller, 2002: 75). Inderdaad, alle menslike kennis is "ten dele", voorlopig, kwesbaar en korrigeerbaar van aard.

\subsection{Kritiese opmerkings}

- Om te begin, moet opgemerk word dat daar werklik niks nuut is wat in die standpunte van die Nuwe Hervorming na vore kom nie. Nagenoeg alles wat hulle as "nuut" voorstel, het reeds in een of ander vorm in die Vroeë Kerk (vgl. die Marcionisme en Manigeïsme) en in die liberale teologie van die negentiende en twintigste eeu in veral Duitsland, Nederland, Engeland en die VSA voorgekom. Standpunte van liberale teoloë soos onder andere Ritschl, Von Harnack en Bultmann is orals terug te vind. lemand wat die standpunte van die Nuwe Hervorming as "nuut" voorhou, moet óf aan teologiese geheueverlies lei óf onkundig wees ten opsigte van die teologiegeskiedenis van 2000 jaar. Al wat nuut is, is dat dit tans in Suid-Afrika op 'n wetenskaplike wyse aangebied word soos nog nooit voorheen plaasgevind het nie (vgl. Hanekom, 1951).

- Die standpunte van die Nuwe Hervorming impliseer 'n radikale breuk met die kerk- en teologiegeskiedenis van 2000 jaar. Dit is vir my baie moeilik om, op die basis van die teologie van die Nuwe Hervorming, enigsins sinvol om te gaan met (onder andere) die geskrifte van 
Atanasius en Augustinus, Luther en Calvyn, Bavinck en Barth.38 Ek vind dit 'n onhoudbare argument dat hierdie teoloë die evangelie op húlle manier vir húlle tyd op 'n manier vertolk het waarby ons vandag geen aansluiting meer kan vind nie, altans wat die kern van die evangelie betref. Ook die ekumeniese en reformatoriese belydenisskrifte word binne die nuwe raamwerk eintlik maar antikwariese geskrifte.

- Ek ondervind ernstige probleme daarmee dat die moderne wêreldbeeld en teologiese wetenskap as (deurslaggewende) hermeneutiese sleutel hanteer moet word vir 'n korrekte Skrifverstaan. Dit impliseer dat premoderne mense in Afrika die Bybel nie meer sinvol kan lees nie en dat 'n juiste Skrifverstaan (hoofsaaklik) afhanklik gemaak word van die interpretasies van vakteoloë. Dit is 'n onaanvaarbare vorm van moderne sciëntisme.

- Ek sou graag wou sien dat die Nuwe Hervorming veel kritieser omgaan met hulle eie voorveronderstellings, want haas oral loer daar by hulle 'n baie naïewe kritisisme om die hoek. Ook die Nuwe Hervorming beoefen nie die (teologiese) wetenskap op 'n waardevrye manier nie, maar gaan van bepaalde (soms versluierde) voorveronderstellings en soms selfs vooroordele uit (byvoorbeeld dat die Bybel noodwendig krities gelees behoort te word - 'n voorveronderstelling wat lynreg indruis teen die eie-aard van die Bybel.) As dit dan 'n valse aanspraak is dat "die ortodokse verwoording dieselfde siening as die Bybel huldig" (Craffert, kyk Muller, 2002:78), dan is dit óók 'n valse aanspraak dat die kritiese benadering noodwendig dieselfde siening as die Bybel huldig. Die kritiese teologie besit nie alleenreg op "wat die Bybel régtig sê nie" (vgl. Craffert, 2002c).

- Ek kan tot geen ander konklusie kom nie as dat, volgens die standpunt van die Nuwe Hervorming, die hele Ou Testament en die grootste deel van die Nuwe Testament, hoogs problematiese dokumente is en dat hulle boodskap slegs sinvol verstaan kan word indien dit aan 'n proses van radikale ontmitologisering onderwerp word. Ek ondervind groot moeite om die Christelike geloof op sulke twyfelagtige en selfweersprekende dokumente te bou.

- Daar is reeds opgemerk watter probleme daar rondom die Godsleer, die Christologie en die eskatologie bestaan. Dit val op dat daar in die Nuwe Hervorming baie min oor die Heilige Gees (Pneumatologie) gesê word. Daar word wel baie gepraat oor "'n nuwe spiritualiteit"

38 Botha (kyk Muller, 2002:178) merk wel op dat nie alles van die Kerkvaders verkeerd is nie. Hy spel egter nie uit wat by hulle aanvaarbaar sou kon wees nie. 
(Muller, 2002:225-236), maar nêrens word dit met die Heilige Gees verbind nie. 39

- Volgens die standpunte van die Nuwe Hervorming kom die totale kerklike liturgie, inklusief die doop, Nagmaal en kerklied, in gedrang en sal dit alles grondig hersien moet word. Kersfees en Paasfees (en Pinkster?) sal waarskynlik slegs sinvol gevier kan word nadat ook hier die proses van ontmitologisering voltrek is.

- Ek ondervind onoorkomelike probleme om, volgens die program van die Nuwe Hervorming, die evangelie van Jesus Christus aan die oorwegend premoderne mense van Afrika te verkondig. Is die deursneemens in staat om die denkgimnastiek van 'n ontmitologiseringsprogram te begryp? Dit is ook nie duidelik óf, en indien wel, hóé, sendingwerk met hierdie benadering moontlik en nodig kan wees nie. Nêrens anders as juis in Afrika blyk dit dat die lyne van premodernisme, modernisme en postmodernisme mekaar deurkruis en nie as afgebakende tydsgrense hanteer kan word soos by Eurosentriese denkers die geval is nie. Trouens, Afrika, met sy oorwegend ongeletterde bevolking, ervaar nou vir die eerste keer die windstote van modernisme en rasionalisme. Ek sou graag van die Nuwe Hervormers wou weet of hulle kans sien om, aan die hand van hulle teologiese benadering, die evangelie van Jesus Christus in Mamelodi te preek. Is hulle bereid om selfs in ' $n$ wit gemeente in Pretoria so onverbloemd en deursigtig te preek dat hulle standpunte duidelik deurkom?

- Die vraag na die sentraliteit van Jesus van Nasaret bly ook onbeantwoord. Indien Jesus niemand meer was as 'n buitengewone mens en niks meer gedoen het as om 'n pragtige voorbeeld van 'n offervaardige lewe na te gelaat het nie, waarom dan juis aan hóm soveel aandag bestee? Waarom nie aan Boeddha of veral Gandhi nie, wat immers polities soveel meer bereik het as Jesus (vgl. Yankey, 2001:142-170) - oënskynlik altans?

- Wie die ontmitologiseringsprogram konsekwent toepas, moet uiteindelik by die volgende vraag uitkom: behoort die geloof in ('n) God nie ook ontmitologiseer te word nie? Waarom nog hoegenaamd gló? Is die geloof self nie nog deel van 'n mitologiese wêreldbeeld waarvan ons so gou moontlik ontslae behoort te raak nie?40

39 Vergelyk Jordaan (kyk Muller, 2002:56) se opmerking dat die sentrum van Christelike spiritualiteit daarin bestaan dat die koninkryk van God reeds "binne en tussen ons is" 'n stelling wat, binne die korrekte konteks en reg verstaan, beaam sou kon word.

40 Vergelyk hier die volgende opmerking van Van de Beek (2002:356): “Jaspers (1954) wijst er al op dat bij een totale ontmythologisering zoals Bultmann (1948) op grond van het moderne wereldbeeld vraagt, het niet in te zien is waarom God daarvan uitgesloten 
- Ten slotte ondervind ek ernstige probleme met die karikatuur wat talle skrywers van die Nuwe Hervorming van die "ortodoksie" maak. ${ }^{41}$ Ek het vrede daarmee dat aan die begrip "ortodoksie" 'n algemene betekenis gegee word - teologies-histories gesien word die begrip gewoonlik verbind met die (redelik verstarde) na-Reformatoriese teologie, maar om ekstreme, fundamentalistiese standpunte sommer so aan die ortodoksie toe te skryf, is eenvoudig nie wetenskaplik verantwoord nie.

\section{Slot}

Wat die Nuwe Hervorming betref, staan ons uiteindelik voor 'n haas ondraaglike dilemma. Ek het die standpunte van die Nuwe Hervorming persoonlik een vir een ernstig oorweeg - en het daarna gevoel of ek deur sewe rolle lemmetjiesdraad gekruip het - maar bevind dat as ek dit moet aanvaar, ek my Christelike geloof, wat ek by my ma en ouma gehoor het (vgl. 2 Tim. 1:5), sal moet prysgee. Aan die ander kant hoor ek die voorstanders van die Nuwe Hervorming aanvoer dat, as hulle aan die klassieke uitdrukking van die Christelike geloof moet vashou, hulle nie meer langer sal kan glo nie. Die vraag ontstaan: praat ons nog van dieselfde geloof? Is 'n geloof in 'n onpersoonlike God nog dieselfde as geloof in 'n persoonlike God, die God van Abraham, Isak en Jakob, die Vader van Jesus Christus? Is 'n blote Jesus-geloof nog dieselfde as 'n Here-Jesus-Christus-geloof? Moet ons nie maar oop kaarte speel nie en sê dat ons by 'n skeiding van die weë gekom het, baie groter as wat Paulus en Barnabas in Antiogië (Hand. 15) ervaar het, ja, selfs groter as

zou zijn. Noch het Joodse noch het christelijke geloof verdraagt zich met het uitgangspunt van de Verlichting."

41 Voorbeelde van karikaturisering in die boek (kyk Muller, 2002) is die volgende:

- Die indruk wat geskep word dat ook gereformeerde kerke die neerdaling na die hel letterlik sou verstaan het (11).

- Die indruk wat geskep word dat die klassieke Evangelies nie sou leer dat die koninkryk van God reeds in hierdie lewe (voorlopig altans) bereik kan word nie (15).

- Die indruk wat geskep word dat tradisionele kerke God nét as 'n wraakgierige God sou voorhou (20).

- Die voorstelling dat die ortodoksie voorgee om alle vrae te beantwoord (18).

- Die voorstelling dat die ortodoksie slegs 'n letterlike interpretasie van (alle) tekste handhaaf $(70,99-100)$.

- Die voorstelling dat 'n dualistiese antropologie algemeen aanvaar word (83).

- Die voorstelling dat die drieverdieping-wêreldbeeld die oorsprong sou wees van die leer oor die openbaring en inspirasie (205).

- Die voorstelling dat net die ortodoksie etnosentries sou wees (221) - asof die liberale teologie altyd humaan ingestel is, iets wat deur die teologiegeskiedenis volledig weerspreek word. 
dié tussen Rome en Reformasie in die sestiende eeu, en wat, voorlopig altans, onoorbrugbaar skyn te wees? Het ons nie in die Nuwe Hervorming te doen met 'n "ander evangelie" in plaas van met 'n "ander weergawe" van die evangelie nie?

\section{Bibliografie 42}

BARRY, A.T. et al. 2002. Brief. Die Kerkbode, 2 Augustus.

BAVINCK, H. 1908. Wijsbegeerte der openbaring. Kampen : Kok.

BERKHOF, H. 1990. Christelijk geloof: Een inleiding tot de geloofsleer. Nijkerk : Callenbach.

BULTMANN, R. 1969. Geloof zonder mythe. Roermond : Romen.

BURGER, I. 2002. Nuwe Hervorming? - Pure New Age. Algemene Kerkbode, 8/9/10 Augustus.

CALVYN se Kategismus (1981). Potchefstroom : PTP. (Vert. H.W. Simpson.)

CALVYN, J. 1984-1992. Institusie van die Christelike godsdiens 1559. Potchefstroom : CJB. (Vert. H.W. Simpson.)

CILLIERS, J. 2001. Hoe word 'n mens gered? (In Meiring, P., red. So glo ons: Gelowig nagedink oor God, die Bybel en ons leefwêreld. Vereeniging : Christelike Uitgewersmaatskappy. p. 185-198.)

CRAFFERT, P.F. 2002a. Wis uit vs praat dit uit. Beeld, 18 Sept.

CRAFFERT, P.F. 2002b. Is dít billike kritiek? Die Kerkbode, 14 Okt.: 5.

CRAFFERT, P.F. 2002c. Wat sê die Bybel regtig oor ... die hel? Pretoria : Unisa.

CRONJÉ, F., KIRKPATRICK, J. \& NAUDÉ, E. 2003. Luister na álmal. Die Kerkbode : 7, Maart 28.

DEN HEYER. C.J. 1996. Opnieuw: Wie is Jezus? Balans van 150 jaar onderzoek naar Jezus. Zoetermeer : Meinema.

DU PLESSIS, I. 2003. God en wetenskap - en ons wat glo. Wellington : Lux Verbi.BM.

DU RAND, J.A. 2001. Wat weet ons van Jesus van Nasaret? (In Meiring, P., red. So glo ons: Gelowig nagedink oor God, die Bybel en ons leefwêreld. Vereeniging : Christelike Uitgewersmaatskappy. p. 43-55.)

DU RAND, J., JOUBERT, J., KÖNIG, A. \& VAN DER WATT, J. 2001. Té min bly oor. Die Kerkbode: 10, Aug. 17.

DU TOIT, B. 2000. God? Geloof in 'n postmoderne tyd. Bloemfontein : CLF.

GAUM, F. 2003. Van Huyssteen loop vóór (Vraaggesprek). Die Kerkbode: 12, Jun.13.

GRUDEM, W. 1994. Systematic Theology: An introduction to Biblical doctrine. Grand Rapids : Zondervan.

HANEKOM, T.N. 1951. Die liberale rigting in Suid-Afrika: 'n Kerkhistoriese studie. Stellenbosch : CSV-Boekhandel.

HOFMEYR. H. et al. 2003. Hervormingsgetuienis van 'n aantal bekommerde lidmate. Die Kerkbode: 14, Maart 14.

Inst.

kyk Calvyn, 1984-1992.

JACKSON, N. 2002a. Dié drie teoloë is struikrowers. Beeld: 3, April 11.

42 Omdat dit die bibliografie onnodig lank sou maak, is nie alle verwysings na korrespondensie en artikels in dagblaaie in die bibliografie opgeneem nie, maar is volstaan met 'n kort verwysing in die artikel self. 
JACKSON, N. 2002b. Die man met Bybel-ore (Crossan). Beeld: 10, April 17.

JACKSON, N. 2002c. "Gee ruimte in die geloof". Beeld: 5, Mei 20.

JACKSON, N. 2003. NG Kerk, Nuwe Hervormers se gesprek kan haak. Beeld: 11, Maart 12.

JANSON, M. 2001. Op soek na die ware Jesus: Die hart van ons geloof in die brandpunt. Wellington : Lux Verbi.BM.

JANSON, M. 2002. Muller het met Christus gebreek. Beeld: 14, Feb.13.

KÖNIG, A. 2001. Die helfte is my nooit oor JESUS vertel nie: 'n nuwe kyk op die een wat jou lewe verander. Wellington : Lux Verbi.BM.

KÖNIG, A. 2002a. "Kruisdood is vir húlle afskuwelik": Nuwe Hervorming ry maar op ou donkie. Beeld: 15, Maart 28.

KÖNIG, A. 2002b. Ek glo die Bybel - ondanks al die vrae: Vaste bakens vir 'n tyd waarin die Bybel in gedrang is. Wellington : Lux Verbi.BM.

KUITERT, H.M. 2000. Over religie: Aan de liefhebbers onder haar beoefenaars. Baarn : Ten Have.

LE ROUX, J.H. 2002. Andries van Aarde se vaderlose Jesus. Hervormde Teologiese Studies, 58(1):77-99.

MEYER, M. (trans.) 1992. The Gospel of Thomas: The hidden sayings of Jesus. New York : Harper Collins.

MOLTMANN, J. 1980. Trinität und Reich Gottes: Zur Gotteslehre. München : Kaiser.

MULLER, P., red. 2002. Die Nuwe Hervorming. Pretoria : Protea.

NEL, A. 2003. Op soek na God ... buite die kerk? Wen weer ontnugterde gelowiges se vertroue. Wellington : Lux Verbi.BM.

NHKA, 2002. Verklaring van die Kommissie van die Algemene Kerkvergadering aan lidmate van die kerk oor belydenisaangeleenthede. Die Hervormer: 1, 4, Julie 15.

NHKA, 2002 : Herderlike skrywe: Ring van Waterberg. Die Hervormer, 3, Sept. 1.

POTGIETER, R.M. 2002. Keith Ward and panentheism: An evaluation of Keith Ward's panentheism as a step towards a model for Christian interpretation of cosmology. Potchefstroom : PU vir CHO. (Ongepubliseerde proefskrif.)

RETIEF, H. 2002. Dis g'n ongelowige Tomas dié nie. (Hanlie Retief gesels met Piet Muller.) Beeld: 12, Maart 10.

ROBINSON, J.A.T. 1967. Maar dat kan ek niet geloven! Utrecht : Ten Have.

ROTHUIZEN, G.Th. 1969. Aristocratisch christendom: Over Dietrich Bonhoeffer. Kampen : Kok.

SÖLLE, D. 1993. Denken over God: Inleiding in de theologie. Baarn : Ten Have.

SPANGENBERG, I. 1995. Kritiese realisme, die Bybel, die gereformeerde belydenisskrifte en die Christelike geloof. Religion and Theology, 2(2):191-205.

SPANGENBERG. I. 1998. Perspektiewe op die Bybel: God se Woord in mensetaal. Pretoria : Van Schaik.

SPANGENBERG, I. 2002a. Beleef die Christelike teologie soos met die vorige eeuwending weer 'n paradigmaverandering? Hervormde Teologiese Studies, 58(1):100-117.

SPANGENBERG, S. 2002b. Drie beelde van Jesus. Rapport, 23 Junie.

STANDER, H. 2002. Ek glo steeds in dáárdie Jesus ... Die Kerkbode: 11, Sept. 6.

STOKER, H.G. 1970. Oorsprong en rigting II. Kaapstad : Tafelberg.

VAN AARDE, A. 2001. Jesus - Kind van God, Vaderloos in Galilea. Verbum et Ecclesia, 22(2):401-417. (Hierdie artikel is byna gelykluidend met die artikel oor "Die vaderlose Jesus" wat in Fragmente: Tydskrif vir Filosofie en Kultuurkritiek, 2001(7):91-100, verskyn het.) 
VAN DE BEEK, B. 1996. Schepping: De wereld als voorspel voor de eeuwigheid. Nijkerk : Callenbach.

VAN DE BEEK, A. 2002. De kring om de Messias: Israël als volk van de lijdende Heer. Spreken over God 1, 2. Zoetermeer : Meinema.

VAN DER WESTHUIZEN, H.G. 2000. Nuwe ongeloof. Pretoria : Sentik.

VAN GENNEP, F.O. et al. 1989. Waarlijk opgestaan! Een discussie over de opstanding van Jezus Christus. Baarn : Ten Have.

VAN WYK, D.J.C. (jnr.). 2002. Glo ons nog in dieselfde God? Die Hervormer: 2, Junie 15.

VAN WYK, D.J.C. (sr.). 2002. Bereid tot verantwoording. Die Hervormer. 3, Aug.15.

VAN WYK, G. 2003. God - loerbroer of goeie aarde? Die Hervormer. 6, Junie 1.

VAN WYK, J.H. 1989. Die Woord is waardevol: Dogmatiese besinning oor die reformatoriese Skrifbeskouing. Potchefstroom : $\mathrm{PU}$ vir $\mathrm{CHO}$.

VAN WYK, (Amie) J.H. 2000. "Daarsonder is dit nag": Christelike geloof "staan of val" met Christus se opstanding. Beeld: 23, Okt. 27.

VAN WYK, J.H. 2001. Geloof en wete(-nskap): In gesprek met Ben du Toit. In die Skriflig, 35(1):141-146, Maart.

VAN WYK, J.H. 2002a. In debat met die Nuwe Reformasie. Die Kerkblad: 8-10, Julie 3.

VAN WYK, J.H. 2002b. Fundamentalisme en kritisisme: Nadenke oor Skrifbeskouing en Skrifverklaring - van Augustinus tot Bultmann. In die Skriflig, 36(4):593-620.

VAN ZYL, H. 2002. 'n Alternatiewe Christendom? Die Kerkbode: 9, Nov. 1.

VEENHOF, J. 1990. New Age - Een uitdaging voor kerk en theologie. Gereformeerd Theologisch Tijdschrift, 90(2):84-95, Mei.

VON HARNACK, A. 1903. Het wezen des Christendoms. Leiden : Kapteijn.

VON HARNACK, A. 1931. Lehrbuch der Dogmengeschichte I. Tübingen : Mohr (Paul Siebeck).

WENTSEL, B. 1991. God en mens verzoend: Incarnatie, verzoening, koninkrijk van God. Kampen : Kok.

WENTSEL, B. 1998. De Heilige Geest, de kerk en de laatste dingen. Dogmatiek 4b. Kampen : Kok.

WILLIS, W., ed. 1987. The kingdom of God in 20th-century interpretation. Peabody/Mass : Hendrickson.

WOLMARANS, H. 2002a. Tyd vir 'n nuwe godsbeeld is hier. Beeld: 13, April 17.

WOLMARANS, H. 2002b. As wêreld se 3 verdiepings inplof ... Beeld, Mei 28.

WOLMARANS, H. 2002c. Brief. Beeld, Aug., 19.

WOLMARANS, H. 2002d. Hemelse stories met aardse betekenisse. Woord en Daad, 380:15-18.

WOORD EN DAAD, 2002 (380). (Verskillende getuienisse en verklarings oor die Nuwe Hervorming.)

YANKEY, P. 2001. Soul survivor: How my faith survived the church. London : Hodder \& Stoughton. 


\section{Kernbegrippe:}

Christologie/Jesulogie

Godsleer/panenteïsme

Nuwe Hervorming se ekklesiologie, eskatologie, Skrifleer

\section{Key concepts:}

Christology/Jesuology

doctrine of God (panentheism)

New Reformation: its ecclesiology, eschatology, doctrine of Scripture 
